The mettings of the Canadian Society of Forest Engineers extended over both Wednesday and ihursday. They were held in the Forestry Building and were presided over by Dean Howe as president of the society. Four main subjects were discussed: Silviculture, Utilization of Hardwoods, Estimating, and Fire Protection. The papers read were of ahigh order and there was much free, discussion. A dinner was held jointly with the Foresters' Club on Wednesday evening at which one hundred and twenty-five sat down in the great hall of Hart Housc. Mr. S. . Dana in charge of the Northe astern Forest Experiment station jt. Amherst, Mass., and recently re-elected for a second term as President of the Society of Americun Foresters was the guest of honor and delivered an interesting address on the opportunities for service of the professionil foresters societies in America. The president of the Foresters' Club, Mr. G.K. Lane, B.S.A., '24, was chairman, and $M r$, Arthur Blight sang a group of four songs, which were received with enthusiastic approval.

The concluding event of the week was the annual dance of the Forestry School in Hart House which was attended by a large number of alumni, and was a very pleasant and enjoyable occasion.

\title{
Minutes of the Eighteenth Annual Meeting.
}

The eighteenth annual meeting of the society was held in Toronto January 20-2I, 1926, and was arranged so that it. came at the same time as the opening and dedicatory ceremonies of the new Forestry Building of the University of Toronto. There were scventy-two members and fourteen visitors present as shown by the registration cards. In addition to this number the forty ocd undergraduates in attendance at the school were invited which brought the average attendance of each session well over a hundrea.

The first session was opened Wednesday morning with the president, Dr. Howe, in the chair. The minutes of the lnst meeting, which was held in ottawa, were read. After some questioning by W.N. Millar regarding certain omissions they were adopted as read.

Millar then questioned the power of the president to appoint a new secretary when that office became vacant by the resignation of J.R. Dickson. The president explaincd that as no provision was made in the constitution for filling such vacancies, he had consulted with the other members of the cxecutive who left the final decision to him.

Leavitt then moved that "The executive committee was within its rights and powers in asking $M r$. Richardson to assume the duties of secretary in the interim and, furthermore, that this metting confirm this appointment." Seconded by Millar, carried.

The secretary and measurer then read their reports, copies of which will be found elsewhere in this issue. 
The first prper on the programre was read by D.R. Cameron who presented "The Possibilitics of Silvicultural Practice in our Forcsts, and the ixtent to which Present Legislation already provides for such." Mr. Cameron saw a broad and promising field for the practice of silviculture in this country. While in Europo, recently, he had been impressed by the skillful usc of certain hardwoods among conifers to keep the forest soil sweet and warm and friable, whereas in our pulpwood forests of nearly pure balsam and spruce the soil tended to become incrcasingly sour and impermeable. Here lay a challenge to our silviculturists. Agrin, the solution of the slash-disposal problem in Canada - a silvicultural question - could not be much further advanced in any one province or forest region tantil by goverrmental co-operation the lumbermen everywhere were obliged to carry approximately the same overhead charges for brush disposal. This would prevent unfair diserimination and enable the cost to be passed on to the public, who, after all, own nearly all our timberland and would be the chief beneficiaries from forest perpetuation.

This paper concluded with the thought that as all progress in silviculture was conditinned on research, Canadians could not too soon establish at least one forest experiment station in ench important forest region of Canada, and standardize their research methods.

Mr. R.H. Candy, of Ottawa, then read a thoughtful paper in discussion of $M r$. Cameron's. He was in general agreement with its findings and emphasized the need for the fullest co-oporation and co-ordination in furthering and perfecting a system of nation-wide research, as a guide towards the best silvicultural practice.

This paper inaugurated some healthy discussion as to just what is silviculture. Millar led the discussion and took the ground that no silvicultural or regulative step was justifiable until a resulting financial profit could be elearly demorstrated. With this dictum, Nr. Ellwood Wilson, of Grand Mere, was inclined to take issue. He thought that a paper company, for instance, which had drewn a dependent community around its plant must shoulder a certain moral responsibility for taking such steps in forest management as would tend to guarantee the permanence of their industry for the community dependent thereon.

Professor James loumey, of Yale, said that full forest utilization and good silviculture were so interrclated that he doubted whether any real silviculture was commercially feasible on this continent wherever virgin stands of timber still remained. This second growth stage, however, had already been reached in certrin sections and would rapidly become more general. He felt that the greatest need to-day as affceting both foresters and forest-owners was a system of demonstration forestis of 1,000 to 3,000 acres in size, where each necessary step in approved local forest management would be in actual evidence. 
Mr. Zavitz concurred with Professor loumey regarding demonstration areas and pointed to the use made of such methods by the departments of agriculture. Others taking part in the discussion were, Van Camp, Cameron and Courtnage.

Following this interesting discussion and, as the time for noon recess was at hand, two more items of business were dealt with. A resolutions comrittee was selected consisting of Messrs. Wilson (chairman), Finlayson, Cameron, Edgecombe and Zavitz. A letter of greeting was then read by the President, Ixom the Society of American Fortsters.

At the afternoon session reports from various comrittees were called for. The diploma and certificate committee, of which $\mathrm{Mr}$. Zavitz is convener, made no report. The committee for co-operation with the C.M.A. reported further progress through Mr. Cameron, Clyde Leavitt gavo a statement of articles of members published in Forest and outdoors as constituting the committe's report on publication. Dr. Howe then reported for the Educational Committee and stated that 75 addresses and 40 articles of a popular kind had been delivered and published by members of the society.

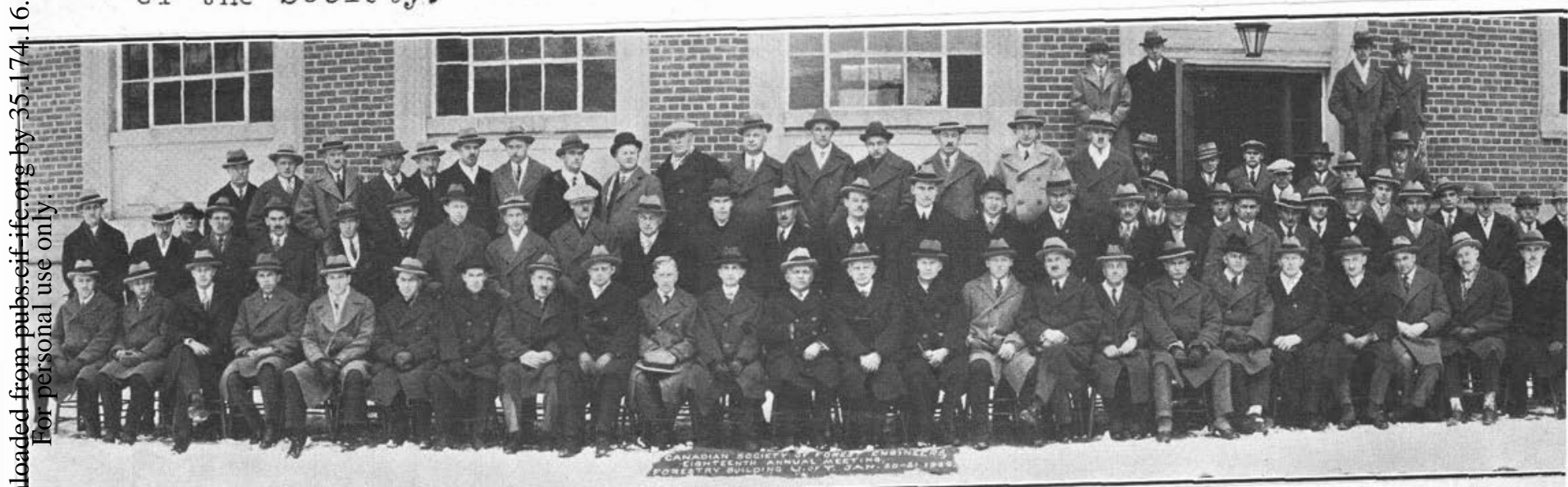

Professor Millar then reported for the Committee on Establishing of a Technical Journal. This report had been mimeographed and distributed to the members and indicated much preparation on the part of the chairman. The adoption of the report was moved by Millar and seconded by Van Camp.

In discussing the report some consideration was given to the proposed increase of subscription rates to the American Journal but, as it seemed definitely known that such increase would not take place, Craig thought it preferabie to continue the way we were at present and increase the influence of the "Chronicle". Icavitt. supported Craig and sugested feeding more popular articlis to Forest and Outdoors. He also pointed out that the Journal gives prestige abrosd to all Canadians who publish articles thercin. Wickenden spoke favouring Craig's and Ieavitt's attitude.

Mr. S.T. Dana President of the American Society, who was a guest at the mettings, then made a statement regarding the Journal and said that the subscription price would not be raised this year. He pointed out that the Journal had a wide circulation outside of the U.S. which gives all contributors to it an international influence. Besides, he said the Journal is perhaps the greatest connecting bond between the American and Canadian 
Societies and for this reason aloue he would not like to see the Canadian society withdraw. Others taking part in the discussion were - Van Canp and Robertson.

Cameron then moved an amendment to the report, seconded by Leavitt, that "we elect an editorial board of three to take off Mis. Richardson's hands the publication of the Forestry Chronicle and that this be used as the organ of the Society in mimeographed form for the coming year." Carried. Motion lost.

Iir. R.G. Lewis, of the Dominion Bureau of Statistics, then read a paper on "Progress in the Utilization of the Hrrdwoods in astern Canada." He wisted out that shrinkage in the supily of the more valuable species was causing new uses to be found continually for our hard maple and yellow birch. M:. Wis. Iynoch, Superintendent of the Iuntreal Forest Products Laboratories, ably led the discussionion Mr. Luwis' yaper. In the next paper, M. R.A. Cuurtnage described the success attained in an extended series of experiments on the driving of hardwoods. The most successful method and the one most generally followed by lumbermen in ontario was to peel the $10 \mathrm{gs}$ in May or June and let them lie about a week on the water's edge. They have then lost some 15 percent of moisture content but without any serious checking, and when rolled into the vater will float for two or three months with very slight loss from shrinkage.

Tris paper was iliustrated with lantern slides which made the subject more interesting.

C.H. Irwin then led the discussion by reading a short paper. Nisbet told the meeting of his experiences in similar work. others taking part in the discussion were Robertson, Hillar, Kynoch, Cameron, Campell and Cousens.

AIter this session all adjourned to the courtyard where a photooraph was taken.

On wednesday cvening, the business sessions were broken into to enjoy a delightfuliy appoisted dinner in the Great Hull of Hart House, with a congenial after-programme of music and addresses in the cozy atmosphere of the Music Room. Samuel T. Dema, President of the Society of American Foresters, was a welcome quest and gave a much appreciated talk on the ethics and work of a forester.

Trursday morning, Hr. Cameron again opened the subject of a society publiaation and explained the reasor of his amenament of the previous day pointing out that his intention was to $r \in l i \in v e$ the secretary of some of his duties which he had thought too burdensome together with the Chronicle. The Sucretary stated that he was prepared to continue giving assistance to the Chronicle whereupon orkeron withdrew his arendment of the previous day. After further discussion by carerus, Leerits, Dvizit wa Rokertson, Lunvitt moved, seconded by Cimoron, that an editorial board of seven including an editor-in-chief be ap: ointed 
representing different parts of Crmua; two from Quebec and the East, two from Cntariu, oiso fruh the Pruirius and one from British Columbia. Carcieu. Norinatius iveso called for. Vote was taken by ballot. Canesuil wis Ricmicon scrutinetrs. The election resulted as follows;- Editor-in-Chief, Richardson

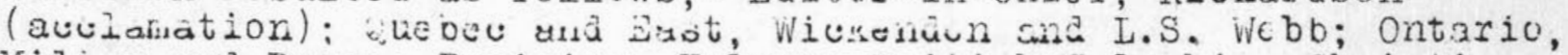
Miliar and Iruce; Prairies, Holmar; British Columbia, Christie.

Mi. G.C. Piche, Chief Forester for Quebec, who was to have read a paper dealing with the subject of silviculture, was not present. Mr. H.R. Wickenden of the Wayagamack company then briefly outlined the method followed in their cutting operations in order to encourage the start of a new crop of timber by natural reproduction. Diameter limit control of felling, he said, had bech abandoned. Instead, selected seed-trees were now carefully marked and left and the most encouraging success in forest reregal. was being secured in this way.

Discussion of this paper was then taken up by Zavitz, who further stressed demonstration tracts. Others taking part in the discussion were Rovertoui, Hillar, Dana, Avery, Couper, Car erun ana Wilson. During this discussion the applicability of growirg certain Durupein species in the cinedian Forest was brought un, particularly that of beech; wilnon, Zavitz, Cmerun, Robertson, Avery, Dalign and HeDougals tarins pist.

Tis President then reminded the members of the Worla's Furestry Cunferexioo at Rome next summer. Mr. Dana made a statement regaraing this and two members indicated their intention of attending.

Professor T.W. Dwight then presented a deeply interesting and valuable paper entitled "istimating the Future Yield of Even-aged Stands". By use of this method, it would appear that practical yield tables might be constructed, applicable to our Canalian mixed stands of varying density. No discussion. Lesvitt in the chair.

Mr. J.A. Brodie then read a carefully prepared paper on "rhe Application of Statistical Methods of Estimating." Mr. W.G. Wright had prepared a discussion paper basea on lir. Brodie's and in his absebce this was read by M⿻. Hersit. Discussion followed, those taking part were Robertson, cousens, Leavitt, Irwin and Dwight.

Mr. Leavitt then read an able paper discussing with many constructive suggestions, "Ihe Progress and Development of Forest Fire protection Methods in Canada." A vigorous discussion followed this paper which finally led into other matters. Nillar questioned the value of propagarda in forestry work, particularly fire protection. Leavitt, winegar and Avery took exception to this and pointed out its value and importance. others taking part were Finlayson, Kilby, Delahey and Haddow. Winegar, on behalf of the C.P.R., expressed appreciation for the work done by the different forest services in suppressing forest fires.this was repeated on behalf of the C.I.R. by Kilby. Mr. 
Zavitz, then thanks these members for their kind words and pointed out that the success of suppression of railroad fires vas attributed to the education and closer co-operation of the employees with the goverurint officers.

At this part of the meeting Nir. Finlayson referred to the new tree book by Dr. White, and praised it for its excellent make-up and for its splendid contrjbution to the general forestry education of the country.

A letter was then read by the secretary from the Deputy Minister of National. Deferce, Air Service, regarding the two types of acroplancs built in accordance with designs suggested by the society.

The question of the next place of metting was brought and Col. Stevenson exterded an invitationto met at Winnipeg. This was supported by Browr who said that a western meeting would give more of the western meri a chance to attend. . Cameron supported the western suggestions. Dwight suggested two meetings, one east and one west. Morse suggestea Calgary. The chairman then ruiea that the executive would decide where the next annual meeting should be held, taking into ensideration the invitations received.

As the Dresident found it necessary to leave the meetings at this time he expressed the appreciation of the other members of the forestry staff and himself, for the splendid attendarce of members at the opening ceremonies of the building and for makirg the meeting of the society such a success. Mr. Leavitt then took the chair.

MoDougald then asked for data and co-operation from all in collecting data for working un forecasting of fire hazard weather, Jalij. then outlined the methods used and the success attained thus far in his inspectorate. Atkinson told of his experiences in this work.

The meeting then adjourned. 
Secretary's Report.

For the year ending December 31, 1925 .

The office of secretary of the society became vacant early in the year through the resignation of Mr. J.R. Dickson. At that time the President asked me to take over the duties of the office until it could be filled in the regular way by an expression of the members.

Since the time of appointrent the following items of note have been carried on for the Society;

1. Printing of the Constitution and Membership List.

The authority for printing this is contained in a motion passed at a metting of the General Executive in ottawa, September 17th,1924. It was felt that the constitution and a list of members should be arailable in convenient form. A copy of these, therefore, was printed and mailed to 211 members of the Society. Early in the new year it is proposed to supplement this with a list of those members whose addresses have changed since its publication, together with a list of newly elected members.

2. Questionnaires.

At the last annual meeting the suggestion was made that the secretary gather professional and personal data from all members of the Society. This was obtrined by means of a two page questionrizire. Up to date 80 per cent of the members have been good enough to return these. In most cases the information asked for was given in detail but many, evidencing, I suppose, that modesty which is characteristic of the profession, omitted the mount of salary received. The information on these questionnaires can be used in connection with enquiries re employment and in years to come should also be of historical interest. Needless to say, these forms, as is the case with all Society files, are held in strict confidence.

\section{3. "Forestry Chronicle".}

Following the discussion at the last annual meting regarding $a$ technicil journal, the sppearance of the "Forestry Chronicle" must have come as a surprise to many of the members. Its form, however, was legitimately cvolved from the news letter of former years. This came about as follows;

I found that I was expected to issue from time to time, a news letter of a few prges contrining items of a personal nature as wCIl as Society affairs. Also, it had been customary to send out fron time to time articles of members which fell in a class between being popular enough for "Forest and 
Outdoors" and not of sufficient gener:I interest for the "Journal". Inste zd of sending the se out as they come along I decided to save them up for two or three months, place them in an inexpensive binder and ail them out in a booklet form. When this was done the matcrial contained could hardly be called a news letter, so the name "Forestry Chronicle"was given.

4. Notice of motion to amend the Constitution.

Notice of motion to amend the Constitution was sent to 311 members, pending any actions which the Americin Society might take regarding the proposed increase in fecs and subseription price for the "Journal". As our fees are based on the subseription to the "Journal" it would necessarily mean an increase in ftes if the subscription price wcre changed.

At the annual meeting of the society at Madison in December, some time was given to discussion of this matter and the opinion was expressed that it was not desirable to raise the fees or the subscription price. Nothing has reached me yet regarding definite ation on this point, but word from president Dana and Mr. Zon, the editor, indicate that there is little liklihood of an increase being made in the subscription price.

\section{Membership.}

our society continues to have a heslthy increase in membership. At the last annual metting the number stood at 204 , at the end of this year the number was 227 .

During the year 28 new members were elacted and 5 were removed from the roll, 2 by death, 2 for non-payment of dues and 1 resigned.

All of which is respectfully submitted,

Signed A. H.Richardson. 
Report of Treasurer, as of December 31, 1925.

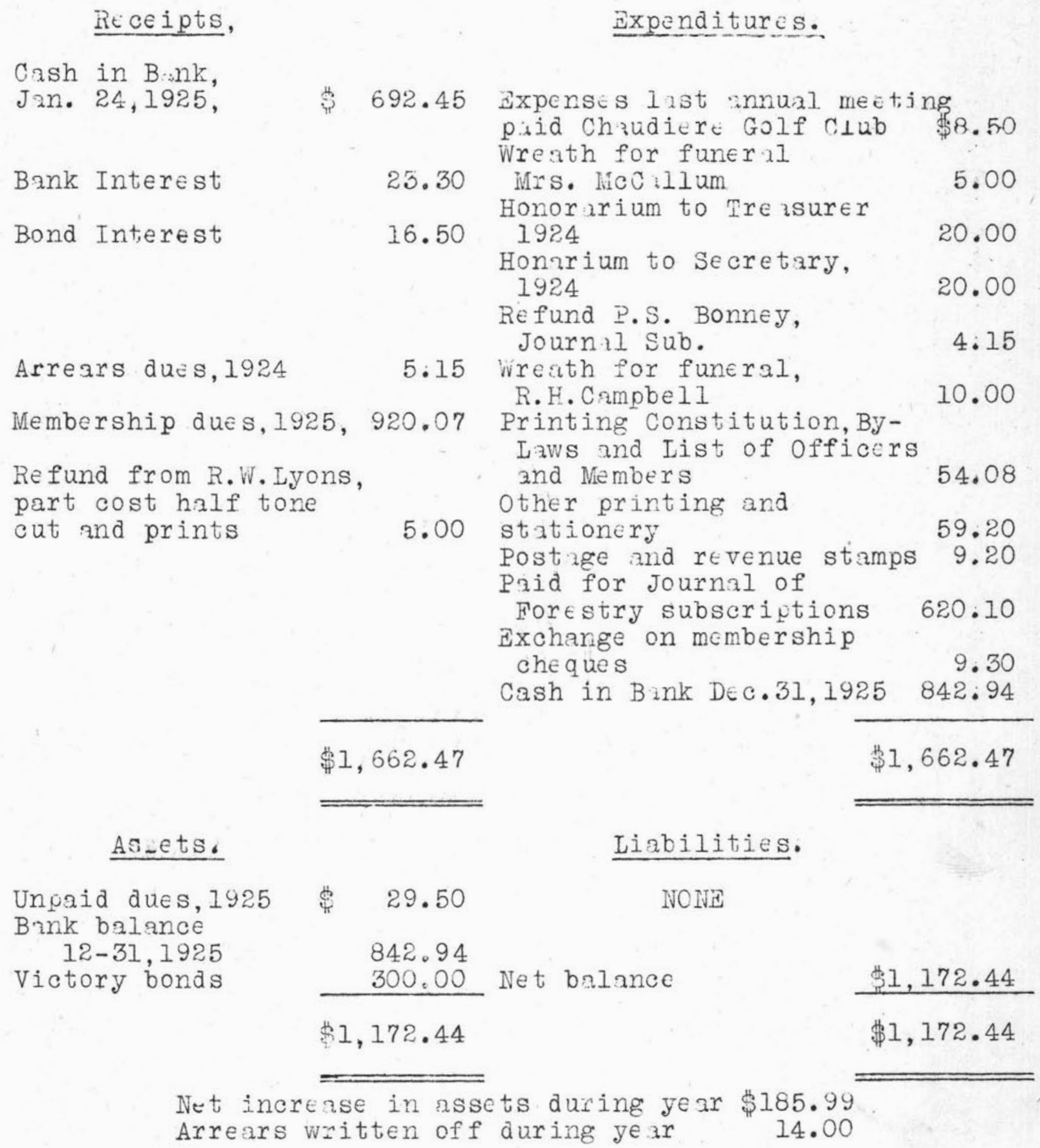

Dropped from lifembership List, two years in arrears for dues, one Associate and one Active member non-resident, involving a net loss to the society of $\$ 8.00$ for Journal of Forestry Subscriptions incurred before suspension, plus $\$ 6.00$ for dues exelusive of Journal.

Audited and aproved by

(Sgd) Roland D. Craig

(Sgd) Clyde Leavitt,

(Sgà) Jimés R. Dickson Treasurer.

December 31,1925. 
Report on Committee on Astablishment of a Technical Juurnal. by C.S. of T..

The Comrittee provided for at the annual mosting in January 1925"to canvass the entire situation with regard to the proposal to establish an independent technic zl journil under the auspices of the C.S. of E.E." uues to report as follows:-

1-The Committee in the absence of specific instructions is agreed that its responsibility is limitcd to passing upon three questions namely:-

(a)-Is it financially practicable for the society to establish and supiort its own technical organ?

(b)-Are there reasonable grounâs for anticipating that sufficient material riny be seared to fill a journal of the size that may be produced within the limits of the Society's financizl means?

(c)-What further action should the society take in case it is deciaed to undertake the establishment of an independent journal?

2-Financial Possibilities- The Comrit;et is agreed that it is entirely possible for the society to maintain its own organ if. the following conditions are approved:-

(a)-To abandon subscription to the Journal of Forestry.

(b) - To assess each member of the Society $\$ 4.00$ a year for the support of our own Jcurnal.

(c)-ro limit the journal to four issues a year and to 64 pages per issue.

(a)-To pay no gratuties or honararia.

The Comrittee has secured offers fron reliable publishers on the cost of printing, binding and distributing such a magazine and finds that the offers 1 ie between $\$ 111$ and $\$ 224$ $p \in r$ issue for an issue of 250 copies with a charge of $\$ 8.50-$ $\$ 10.00$ for each 100 aditional copies. The committee has therefore estimated the total annual cost of a quarterly magaine as follows:- 
Printing and binding..................... per annum $\$ 480.00$ (4 numbers-64 pages-250 copies each)

Enve lopes for mailing.................... Cost of mailing 4 issues of 250 copies......." " " 5.00 Addressing.........................." " 4.00 Stationery and postige..................." " 25.00 $\$ 017.00$

An issue of 500 copies quarterly is estimated to cost $\$ 560.00$

3-Material for the Journal-The Committee is agreed that the Journal should appe ar in toth the inglish and the rrench langurges, papers being published in the language in which they are prepared by the authors.

The average length of papers in the Journal of Forestry is about seven pzoges. On t.tis basis each quarterly issue of the proposed organ may contain 8 papers or 32 papers per year leaving the rest of the space for other departments. The papers presented at the annual meetings of the society number 8 to 10 or enough to fill one issue.

The Committee finds that during the past year alone 31 Canadian foresters have published 40 papers on technical subjects which have appeared in five different publications including the Journal of Forestry and the Forestry Chronicle.

4-Action Recommended-The Comititee recommends the adoption of the following resulutions:-

"That the treasurer of the C.S. of F. E. be instructed to cancel all subscriptions in the names of members to the Journal of Fo-estry after aue notice of intention to the Eaitor of the said Journal and that a Committe $\epsilon$ of seven be elected by this meeting from among the members present to organize at once for the following purposes:-

(a) -To present one or more names of candidates for the position of Ecitor-in-Chicf of the proposed Journal to the Society at large to be voted on by letter ballot before the next annual meting.

paper.

(b)-To draft a statement of the objects of the proposed

(c)-To draft a scheme for the editorial and business management of the Juusnal.

(d) To rocomiend the relationship which shall exist between the board of management of the Jourial wid officers and executive of the Suciotin.

(e)-Tu repurt at the next annual meting the name of the Bditur-in-Chici and the organization scheme decided upon presenting the same in the form of a resolution for the 
consideration of the socicty, and circulating the report to the entire society at least 3 months before the date set for the next annual meeting."

\author{
Re spectfully submitted. \\ W. N. Millar, \\ Chairman.
}

A. H. Richardson, J.I. Van Camp. 